\title{
Quality spermatic alterations in floriculturists exposed to pesticides in Villa Guerrero, State of Mexico
}

\author{
Griset Martínez-Luna ${ }^{1}$, Fernando Mejia-Sanchez ${ }^{2}$, Jorge Humberto Serment-Guerrero ${ }^{3}$, \\ Julieta Castillo-Cadena ${ }^{2, *}$ \\ ${ }^{1}$ Facultad of Chemistry, Autonomous University of the State of Mexico, Toluca, Mexico \\ ${ }^{2}$ Genetics Laboratory, Center for Research in Medical Sciences, Autonomous University of the State of Mexico, Toluca, Mexico \\ ${ }^{3}$ Department of Biology, National Institute for Nuclear Research, D.F., Mexico
}

\section{Email address:}

jcastillo_cadena@hotmail.com (J. Castillo-Cadena)

\section{To cite this article:}

Griset Martínez-Luna, Fernando Mejia-Sanchez, Jorge Humberto Serment-Guerrero, Julieta Castillo-Cadena. Quality Spermatic Alterations in Floriculturists Exposed to Pesticides in Villa Guerrero, State of Mexico. American Journal of Agriculture and Forestry.

Vol. 2, No. 6, 2014, pp. 284-288. doi: 10.11648/j.ajaf.20140206.19

\begin{abstract}
In Villa Guerrero municipality, floriculture is their first economic activity; there are intensively applied different pesticides alone and in mixtures. They fumigate every day, every second or third day, and men, women, children and third age people participate. The use of prohibited or restricted pesticides such as Tamaron, Temik and Curacron in agricultural activities brings health problems with them, especially in their reproductive health. The aim of this study was to determine whether occupational exposure to pesticides alters semen quality. It was held in an exposed group conformed by 30 male floriculturists and the non-exposed group were 30 university male students. All of the participants gave a semen sample and sign an informed consent. There was made a spermatobioscopy accord to the WHO/PAHO (2010). The spermiogram's results in the exposed group showed: significant reduction in the sperm count, in the progressive fast and slow mobility as well as in the normal sperm average. On the other hand, there was a significant increase in the morphologic sperm abnormalities: big, small and double head; short, long and double tale, in comparison with the non-exposed group. Conclusion: it appears that the occupational exposure to pesticides changes the sperm quality.
\end{abstract}

Keywords: Sperm Quality, Pesticides, Floriculturists

\section{Introduction}

Nowadays there is a concern about the toxic effects of the utilization of pesticides in agricultural activities that is because of the high number and its diverse chemical composure, as well as to method of use, time of use, inappropriate choice of pesticides, etc ${ }^{[1,2]}$. The risk of adverse reproductive and developmental disorders due to occupational pesticide exposure has been evidenced. The male gender is the one in which there has been identified a higher number of reproductive effects by the occupational exposure, being the most important ones: the gonadotropin levels alteration, low seminal volume, reduced sperm count, cytotoxic and cytokinetic alterations, morphologic abnormalities, alterations in mobility and loss of integrity of the sperm membrane, increasing the occurrence of oligozoospermia, teratozoospermia y astenozoospermia, as well as the increase of blood levels of the follicle stimulating hormone ${ }^{[1-5]}$. Meantime, in expose women, the identified effects are variations in hormonal concentrations, spontaneous abortion, congenic defects, delay growth of the fetus and low weight at birth of the product ${ }^{[6-8]}$.

In flower production, there are used diverse pesticides to counteract plagues, insecticides, fungicides and acaricides mainly. Related to their chemical structure, the most used are benzimidazole, triazole, chlorated, pyrethroids, organophosphates, phenylanine, dithiocarbamates, imidazole, carbamates and dicarboximide. Between the high and extremely toxic ones there are Tamaron, Temik and Curacron ${ }^{[9]}$.

The State of Mexico occupies 6,740 hectares (1\% of the state territory) in the flower production. The municipality of Villa Guerrero contributes with $80 \%$ of the flowers exported to North America and Europe. The floriculture in this entity is the first economic activity, it has the higher number of greenhouses in the state, were there are applied intensively and in mixtures different kinds of pesticides, both in open 
environments and in closed ones, it is surrounded by a mountain system, which generates conditions that contributes to the permanence of the substances in the atmosphere. The application of pesticides in mixture form is done every day, each second or third day; it is done by men, women, children and third age people, with the minimum of protection equipment and with total ignorance of the health normativity [9-11].

Finding a relation between the occupational exposure to pesticides with health damage requires to drop out the disciplinary investigation models and begin the bonding between different areas of knowledge that allows a full comprehension of the problem. That is why this study pretends to give information about the possible association between the sperm quality and the occupational exposure to pesticides.

\section{Materials and Methods}

\subsection{Subjects}

The exposed group was formed by 30 male floriculturists, from the Villa Guerrero municipality, in the State of México. The non-exposed group was integrated by 30 male members of the Autonomous University of the State of Mexico (UAEMex), Toluca, Mexico. The participation was by invitation and voluntarily, those who accepted signed an informed consent. All participants gave personal and occupational data as well as a semen sample which was held at $37^{\circ} \mathrm{C}$ until it was processed.

\subsection{Spermatobioscopy}

It was made according to the established criteria by WHO/PAHO $201{ }^{[12]}$. The physical and chemical characteristics of the sample were examined: appearance, color, volume, viscosity and liquefaction time.

\subsection{Microscopic Examination}

\begin{tabular}{|c|c|c|c|c|c|}
\hline Tradename & Active ingredient & Chemical group & Biological activity & Toxicological classification & Frequency use (\%) \\
\hline Lannate & Metomilo & Carbamate & Insecticide & $\mathrm{H}$ & 83 \\
\hline Manzate 200 & Maneb & Dithiocarbamates & Fungicide & $\mathrm{S}$ & 73 \\
\hline Furadan & Carbofuran & Carbamate & Insecticide & $\mathrm{H}$ & 73 \\
\hline Tamaron & ○ Metamidofos & Organophosphate & Insecticide & M & 70 \\
\hline Agrimec & Abamectina & Lactone & Insecticide Acaricide & M & 67 \\
\hline Ridomil Gold & Metalaxil-M & Acid ester Metilpropionico & Fungicide & $\mathrm{S}$ & 60 \\
\hline Benlate & Benomilo & Thiocarbamate & Fungicide & $S$ & 50 \\
\hline Talstar & Bifrentin & Carboximides & Insecticide & $\mathrm{S}$ & 47 \\
\hline Nuvacron & ○ Monocrotofos & Organophosphate & Insecticide Acaricide & $\mathrm{H}$ & 43 \\
\hline Tecto & Tiabendazol & Benzimidazole & Fungicide & $\mathrm{S}$ & 43 \\
\hline Pentaclor $600 \mathrm{~F}$ & ○ Quintozeno & Chlorobenzene & Fungicide & S & 40 \\
\hline Fungicel & Mancozeb & Dithiocarbamates & Fungicide & S & 37 \\
\hline
\end{tabular}

OPesticides which are prohibited in other countries but authorized in Mexico.

$\mathrm{S}=$ slightly toxic

$\mathrm{M}=$ moderately toxic

$\mathrm{H}=$ highly toxic

Mobility: It was made a fresh preparation of approximately $10 \mu \mathrm{L}$ of semen in a slide. It was analyzed under the microscope characterizing the movement of 100 spermatozoa and the percentage was reported, taking into account the next criteria: Quick progressivity, a-b grade: Straight, fast movements, travel more than $25 \mu \mathrm{m} / \mathrm{s}$. Slow progressivity, c-d grade: Without sperm progression, but with flagellum mobility or without mobility.

Morphology: A smear was made with $10 \mu \mathrm{L}$ of semen, there were counted 100 spermatozoa and they're morphologic characteristics were reported by percentage.

a) Head: double, big, small, pin.

b) Neck: double.

c) Tale: double, short, long, without tale.

Spermatozoa count: There was made a dilution 1:20 with Macomber and Saunders solution, a drop was placed in the Newbauer chamber, letting the filling by capillarity to occur, after a few minutes in which the sperm settled the microscopic examination was made. The calculation was made and the spermatozoa number was reported $\times 10^{6} / \mathrm{mL}^{[12]}$.

\subsection{Statistic Analysis}

In order to determine the differences of mobility, count, $\mathrm{pH}$ and semen volume between the exposed and the non-exposed group, a Mann-Whitney test was made. A Shapiro-Wilk test was made for the differences in the normal and abnormal sperm count between the groups. The Sigma-Plot 12.0 Systat Software Inc. software was used.

\section{Results}

\subsection{Sociodemographic Characteristics}

The exposed group had an average age of 29 years old, in a range between 17 and 56 years old, on the other hand, the non-exposed group had an average age of 27 years old, in a range between 18 and 63 years old.

Table 1. Floriculturists' most used pesticides. 
The activities of the exposed group were: planting (17\%), pull apart the flower button from the rest $(14 \%)$, cutting (17\%), putting together the packs (15\%), spraying (18\%), weeding $(13 \%)$ and others such as watering, fertilize and packing $(6 \%)$. The most used pesticides for the exposed group were Lannate, Manzanate 200, Furadan, Tamaron, Agrimec and Ridomil gold. The application was in mixture the most of the times, those were form by different biological activity compounds, different chemical group and different toxicity, the Table 1 shows the most used pesticides. Talking about the protection equipment used for the flower growing, $41 \%$ if the individual wore boots, $23 \%$ wore apron, $18 \%$ wore mask and 9\% wore gloves, whereas the non-exposed group activities were mostly academic activities.

\subsection{Spermiograms}

In the spermiograms there were found significant differences between the exposed and the non-exposed group in the progressive mobility (PRM), slow progressive mobility (SPM), sperm average count and normal and abnormal percentage. While in the $\mathrm{pH}$ and seminal volume, there were no significant differences between the groups. The data details are represented in Table 2.

Table 2. Results and statistics analysis of the physical and chemical characteristics of the semen samples of the groups.

\begin{tabular}{llllllll}
\hline \multirow{2}{*}{ Group } & Mobility & & Count & pH & Volume & Spermatozoa & Normal \% \\
\cline { 2 - 7 } & PRM \% & SPM \% & No. sperm $\mathbf{1 0} / \mathbf{m L}$ & & mL & Abnormal \% \\
\hline Exposed & $71^{*}$ & $29 *$ & $61^{*}$ & 8 & 2.0 & $56.5^{*}$ \\
Non-exposed & 86 & 14 & 84 & 8 & 2.3 & 59.0 \\
\hline
\end{tabular}

* Significant difference, exposed versus non-exposed, Mann-Whitney's U test, $\mathrm{p}<0.001$

On the other side, the evaluation of morphological abnormalities in the sperm was made, finding significant differences in parameters as head size increased, head size decreased, double head, double tale, short tale and long tale, between the exposed group and the non-exposed group. At the same time, for the pin head, double neck and without tale, there were no significant differences. All of the results are represented in Table 3.

Table 3. Results and statistical analysis of the abnormalities in the spermatozoa.

\begin{tabular}{lllllllll}
\hline \multirow{2}{*}{ Group } & Head & & & & Neck & Tale & \\
& Macro & Micro & Pin & Double & Double & Short & Long & Withno \\
\hline Exposed & $9.5^{*}$ & $8^{*}$ & 9.0 & $2.0^{*}$ & 1.93 & $8.0^{*}$ & $10.0^{*}$ & 1.0 \\
Non-exposed & 7.0 & 5 & 10.0 & 1.0 & 1.90 & 4.0 & 7.0 & 1.0 \\
\hline
\end{tabular}

* Significant difference, exposed versus non-exposed, Shapiro-Wilk, $\mathrm{p}<0.001$

\section{Discussion}

The result show that more than $40 \%$ of the workers of the study use pesticides such as Furadan, Tamaron, Nuvacron and Pentaclor 600F, which have been restricted in their application by the European Union and the Environmental Protection Agency (EPA) ${ }^{[13]}$. This is due to their high toxicity levels and their impact in the human health, since overexposure to Furadan, Tamaron and Nuvacron triggers headache, dizziness, respiratory difficulty, abdominal spotting, nausea, salivation, blurred vision, dilated pupils, runny nose and mouth, skin bruising, convulsions, tremor, coma and death, as a result of inhibition of acetylcholinesterase or erythrocyte acetylcholinesterase. On the other hand, the Pentaclor 600F, organochlorided pesticide, highly persistent in the environment, it is not clear risk to human health ${ }^{[14-16]}$. Although existing information on the damage to health caused by these pesticides regulations Mexico has not restricted its use ${ }^{[17,18]}$.

These floriculturists are also exposed to Lannate, Manzate, Benlate and Tamaron of which it is known that: methomyl (Lannate ${ }^{\circledR}$ ) is a carbamate, and is known to be environmental estrogen which alters the reproductive system, increasing the abnormal sperm count in mice ${ }^{[14,19]}$. Mancozeb (Manzate $\AA$ ) is a dithiocarbamic fungicide, increases the number of abnormal sperm in mice, and benomyl (Benlate $\AA$ ), a benzimidazolic fungicide, is known to act as an environmental estrogen decreasing testes'weight, sperm count and causes degeneration of the testes in mice ${ }^{[14,20]}$.

The results show the detrimental effects of pesticides on the germ cells, affecting male sperm parameters, so that the sperm may have less probability of a fertilization, fact consistent with other studies such as Hauser et al, (2003), who found a direct relationship between increased environmental exposure to pesticides and less mobility, concentration and percentage of spermatozoa ${ }^{[21]}$, and Abell, et al, (2000), who discussed the role of chemical exposure in the workplace on male reproductive function, associating it with semen quality, finding that spermatogenesis is severely affected by exposure to pesticides in handling greenhouse crops ${ }^{[22]}$.

In this study, there was significant difference in the parameters of sperm quality, finding decreased sperm count, mobility, as well as the number of normal and abnormal sperm and increased structural abnormalities of spermatozoa among the exposed group versus the no exposed. In spermatogenesis, whether pesticides damage to the immature cell, this can cause the damaged sperm cell is removed, so that only those with no apparent damage may mature and eventually leave with the ejaculation, which explains the 
decrease in sperm count ${ }^{[23,24]}$.

Because of this, it must be remembered that the ultimate demonstration of an association between pesticides acting as endocrine disruptors and in generation of reproductive toxicity effects is not immediate, given the difficulty of developing multidisciplinary epidemiological studies, where the cause-effect may be altered over time. Therefore, studies such as this, should be favored, and above all, the continuity of the same, trying to identify the cause-effect relation by the use of pesticides with greater certainty. Meanwhile, it is proposed, to pay attention to the reasonable doubt instructions and the precautionary principle to act preemptively without waiting for irrefutable evidence. Otherwise, the consequences for animal and human health could be dramatic and irreversible.

\section{Conclusion}

The scientific evidence show the negative impact of the pesticides in the occupationally exposed population, as these affects acutely and chronically the male reproductive organs. This research contributes, giving another evidence of alterations in sperm quality induced by exposure to pesticides, in this case, due to occupational exposure with scant protective equipment, with use of prohibited or restricted products internationally and also employing mixtures thereof.

\section{Acknowledgment}

The authors acknowledge the cooperation of all the participants in this study. To Dr. Eduardo Ramirez San Juan for the statistic advice. This project was partially funded by UAEMex, agreement number 3452/2013CHT.

\section{References}

[1] Baños, H.I.; Valdés, C.R.; Castillo, G.I. Male fertility problems due to pesticide exposure. Revista Internacional de Andrología. 2009.7 (2), 98-105.

[2] Golec, J.; Hanke, W.; Dạbrowski, S. Fertility and occupational exposure to pesticides. 2003. Medycyna Pracy. 54 (5), 465-72.

[3] Hanke, W.; Jurewicz, J. The risk of adverse reproductive and developmental disorders due to occupational pesticide exposure: An overview of current epidemiological evidence. International Journal of Occupational. Medicine and Environmental Health. 2004. 17 (2), 223-43.

[4] Robbins, W.A.; Wei, F.; Elashoff, D.A.; Wu, G.; Xun, L.; Jia, J.Y. Sperm ratio in boron-exposed men. Journal of Andrology. 2008. 29 (1), 115-21.

[5] Li, Y.F.; Lin, H.; Ma, M.F.; Li, L.B.; Cai, M.; Zhou, Z.; Xiong, H.; Cao, J. Semen quality of 1346 healthy men, results from the Chongqing area of southwest China. Human Reproduction. 2009. 24 (2), 459-69.

[6] Petrelli, G.; Figa-Talamanca, I.; Tropeano, R.; Tangucci, M.; Cini, C.; Aquilani, S.; Gasperini, L.; Meli, P. "Reproductive male-mediated risk: spontaneous abortion among wives of pesticide applicators” Eur J Epidemiol. 2000. 16 (4), 391-3.

[7] Garcia, A.M.; Benavides, F.G.; Fletcher, T.; Orts, E. "Paternal exposure to pesticides and congenital malformations". Scand J Work Environ Health. 1998. 24 (6), 473-80.

[8] Arbuckle, T.E.; Savitz, D.A.; Mery, L.S.; Curtis, K.M. "Exposure to phenoxy herbicides and the risk of spontaneous abortion”. Epidemiology. 1999. 10 (6), 752-60.

[9] Guía Ambiental para la Floricultura. Descripción del Proceso Productivo. Ministerio del Medio Ambiente y Sociedad de Agricultores de Colombia (SAC): República de Colombia, 2000; 35-

[10] Instituto Nacional de Estadística, Geografía e Informática (INEGI). Encuesta Industrial Mensual, Resumen anual 1999, 1a edicion; Instituto Nacional de Estadística, Geografía e Informática (INEGI): México, D.F., 2000.

[11] Oliva, M.; Rodrigues, J.C.; Silva, G. Estudio exploratorio de los problemas de salud humana derivados del uso de plaguicidas en Bella Vista, Estado de México, México. Manejo Integrado de Plagas y Agroecología de Costa Rica. 2005. 76, 71-80.

[12] WHO/PAHO. Laboratory manual for the examination and processing of human semen. 5a ed; World Health Organization (WHO): Ginebra: 2010; 10-11, 13-16, 21-26, 32-44.

[13] Red de Agricultura Sostenible. Lista de Plaguicidas Prohibidos. Red de Agricultura Sostenible (RAS): San José, Costa Rica; 2011; 2-8.

[14] Yucra, S.; Gasco, M.; Rubio, J.; Gonzales, F.G. exposición ocupacional a plomo y pesticidas órganofosforados: efecto sobre la salud reproductiva masculina. Rev Peru Med Exp Salud Publica. 2008. 25 (4), 394-402.

[15] Otieno, O.P.; Lalah, O.J.; Virani, M.; Jondiko, O.I.; Schramm, K.W. Carbofuran and its Toxic Metabolites Provide Forensic Evidence for Furadan Exposure in Vultures (Gyps africanus) in Kenya. Bull Environ Contam Toxicol. 2010. 84 (5), 536-44.

[16] http://sinat.semarnat.gob.mx/dgiraDocs/ (accessed Oct 2014).

[17] www.ordenjuridico.gob.mx/Documentos/Federal/wo69358 (accessed Oct 2014).

[18] Comision Intersecretarial para el Control del Proceso y Uso de Plaguicidas, Fertilizantes y Sustancias Toxicas (CICOPLAFEST). Catálogo oficial de plaguicidas. Comision Intersecretarial para el Control del Proceso y Uso de Plaguicidas, Fertilizantes y Sustancias Toxicas: México; 2004.

[19] Panger, M.A.; Echeverría, M. Risk of methomyl use to the federally listed California red-legged frog (Rana aurora draytonni). Washington, D.C: Environmental Fate and Effects Division Office of Pesticide Programs; 2007.

[20] Arnold, S.F.; Klotz, D.M.; Collins, B.M.; Vonier, P.M.; Guillette. L.J.; McLachlan J.A. Synergistic activation of estrogen receptor with combinations of environmental chemicals. Science. 1996. 272 (5267), 1489-92.

[21] Hauser, R. Urinary phthalate metabolites and semen quality: A review of a potential biomarker of susceptibility. International Journal of Andrology. 2008. 31 (2), 112-6.

[22] Abell, A.; Ernst, E.; Bonde, J.P. Semen quality and sexual hormones in greenhouse workers. Scandinavian Journal of Work, Environment and Health. 2000. 26 (6), 492-500. 
[23] Recio, V.R.; Ocampo, G.G.; Borja, A.V.; Moran, M. J.; Cebrian, G.M.Organophosphorus pesticide exposure decreases sperm quality: association between sperm parameters and urinary pesticide levels. J Appl Toxicol. 2008. 28 (5), 674-80.
[24] Spira, A.; Multigner, L. The effect of industrial and agriculture pollution on human spermatogenesis. Hum Reprod. 1998. 13(8), 2041-42. 